\title{
Community Participation in Overcoming The Illegal Logging in Sangir Balai Janggo, Solok Selatan District, Indonesia
}

\author{
* Venny Wira Ayu Lestari ${ }^{1}$ and Aung Zin Kyaw Lee ${ }^{2}$ \\ ${ }^{1}$ The Graduate Students of Geography Education, Universitas Negeri Padang, Indonesia \\ ${ }^{2}$ NGO Watch Global Witness, Myanmar \\ Email : vennywirales@gmail.com
}

*Corresponding Author, Received: Februari 10, 2019, Revised: April 10, 2019, Accepted: May 10, 2019

This is an open acces article distributed under the Creative Commons 4.0 Attribution License, wich permits unrestricted use, Distribution, and reproduction in any medium provided the original work is properly cited @2017 by author and Universitas Negeri Padang

\begin{abstract}
The purpose of this study was to know the society's perception in overcoming of illegal logging in Solok Selatan district. This study was a qualitative study by using the key informant. Informants were selected with using purpose sampling technique. The techniques of data collection were observation, interviews, documentation and FGD (Focus Group Discussion). The effort that has been done by the government and society of Solok Selatan district in overcoming the illegal logging is establishing the unity of forest supervision based on area (PHBN), where the supervisory officers were recruited from the community leaders and youth. In conducting forest supervision, local government is always patrolling integrated and give the socialization to the community around the forest.
\end{abstract}

Keywords: Participation, Forest Logging

\section{Introduction}

Indonesia is the biggest archipelago country in the world. Indonesia has a very unique and strategic geographical position, it is located between the Indian Ocean and the Pacific Ocean. Indonesia is also located between two continents, Asia and Australia/Oceania (Hermon, 2012; Hermon, 2015). Therefore, Indonesia has an incredible nature's wealth, one of them is the potential forests which various kinds of growing vegetation (Hermon, 2010; Hermon, 2016; Hermon, 2017). Forests are a very important resource, not only as sources of timber, but rather as one of living environment component. As a result of unwise use of the forest, it evokes many losses where one of them is logging (Hermon, 2001; Hermon, 2009; Hermon, 2011).

Forest is a natural resource that is closely related to human life (Oktorie, 2017; Kristian and Oktorie, 2018; Hermon, 2012; Hermon, 2014; Hermon, 2016), it is important for the country and used for community's welfare, therefore the management should be done well. Forest management has the characteristics which differ with other natural resources management, because forest management is aimed to obtain the optimal benefits for community's welfare without ignoring the nature's characteristics and the principal functions of forest itself, which consists of conversion function, protection function and production functions. Based on that, in forest management, it needs a balance to make those three functions have the important role in supporting the economic development through the production of forest products, timber or non-timber, the protection of area through the conversion of land and water, and the conversion of biodiversity for long-term needs of future generations (Hermon, 2016; Hermon et al., 2017; Hermon et al., 2018). 
One of negative impacts of forest destruction is the illegal logging, which is an unpredictable activity to forest after logging (Oktorie, 2018), because its not in the plan that has been determined. Forest protection is reflected in the concession mechanism loggers (entitlements, permits or land by the government) as a logical consequence of the licensing function as a means of control and oversight. In the management process in order to utilize forest, concept that can integrate efforts to use economic function and the ability of environmental protection efforts in order to keep the environmental state of harmony and balance in accordance with sustainable forest management principle/sustainable (sustainable forest management) and sustainable development (Hermon et al., 2018; Hermon, 2019; Hermon, et al., 2019).

West Sumatra is one of the provinces that implement PHBN in the form of village forest called Nagari Forest. Nagari is a term that describes a society composed of indigenous people into a unitary unit in West Sumatra. The role of nagari in forest management is confirmed in Regulation No. 10 on Communal Land and Regulation 2 of 2007 on the main points of nagari government. The implementation of village forest management means to provide access to the village through village institutions in managing forest resources in a sustainable manner with the participator principle for community development activity, so that the participation of community is needed to achieve that goal. The lack of community participation in the implementation of the forest management program leads to less optimal implementation (Wilujeng, 2015). This indicates that without community participation in the implementation of forest management activity will not take place as it should, so the final purpose of forest management as part of sustainable development, namely as community empowerment especially for forest dwellers will not run well.

The capital city of Solok Selatan is in Padang Aro. Solok Selatan regency consists of seven subdistricts, they are Sangir, Sangir Jujuan, Sangir Balai Janggo, Sangir Batang Hari, Sangir Sungai Pagu, Pauh Duo, and Koto Parik Gadang Diateh. Each of these sub-districts have widely varied, the widest sub-district is Sangir Balai Janggo with 686,94 or about $20,53 \%$ of entire Solok Selatan area. The using of the land is dominated by forest area usage which followed by plantation area usage. Over here, the forest functions as protection forest transformed to palm plantations by the community. Not a few of the communities deforest illegally and get a new land for palms. Illegal logging has now become a serious problem that threatens the environment and human life. Community participation is a medium to obtain information about the conditions, needs, and attitudes of the local community, if they get involved in the policy making process in order to achieve development program. Society has the authority to inhibit the activity if they are not involved in the decision-making process.

Embanaras (2009) revealed the participation is as a manifestation of the desire to develop democracy through the decentralization process which sought, among others, it needs a button-up plan with including the community in the process of planning and community development. Participation comes from the word participation which means taking part, indulgence. Participation means the participation of a person or groups from the process of formulating planning needs to the implementation stage of the activity through the idea or even in the physical activity (Slamet,1994). Hessel quoted Nelson's statements which mentioned there are two forms of participation as follow: (1) Horizontal participation; participation amongst citizens or members of society, where society has the ability to resolve jointly to initiate a development activity and (2) Vertical participation, that the participation of society as a whole with the government, in a relationship where people are in a position as a follower or a client. Thus, a person is said to participate in a development activity if the individual was fully engaged mentally and emotionally, not just being present and being passive towards such activities. Government efforts to tackle illegal logging continues by establishing some policies. Then, the command in addressing illegal logging has formed a Presidential Instruction No. 4 Year 2005 on Eradication of Illegal Logging in Forest Area and Its Distribution in Indonesia.

\section{Method}

This study used a qualitative approach with interactive analysis. In this study, there were two informants: the key informants, ie people who truly understand the problems studied. The key informant referred to in this research was secretary of Sangir Jorong Balai Janggo Sub-District. Furthermore, the nonkey informant was the person who is considered to know the problems being studied. They were the local community. This study examined in depth about public participation on tackling deforestation. Qualitative research is a research conducted with a common and natural background holistically and attempts to 
investigate the problems as a complex phenomenon which needs to be studied as a whole (Maleong, 2007; Okwita, 2009). To obtain the information, the informant selection technique was purposive sampling technique, that is the sampling-taking technique with specific criteria (Matinni, 2018). Basic criteria used include the forest exploited by local people to made as clear land for plantations. The data collected in this study consisted of two types: primary and secondary data. The technique used to obtain data was observational and interview. The method used was to provide relatively similar questions to the informant to collect the same data. The data were considered valid if the data obtained are relatively the same from all informants interviewed.

\section{Result and Discussion}

Sangir Balai Janggo is a sub-district in Solok Selatan District, West Sumatra, Indonesia. The subdistrict capital is located in Jorong Pasar Sungai Sungkai in Nagari Sungai Kunyit. With an area of 686.94, population of 19,434, and the villages there in includes: Nagari Sungai Kunyit, Nagari Talao Sungai Kunyit, Nagari Sungai Kunyit Barat and Nagari Talunan Maju. Since the area is generally dominated by forest area, planted with oil palm and there are also many factories around the region, people often do illegal logging to open up new land or just to take forest products such as timber and then exported to other regions.

The word illegal logging was actually born out of the social issues that would fret drastic reduction in the number of forest areas in the world a result of logging. The reason the government made a policy against illegal logging activities was because the illegal logging is a series of deviant actions that affect the ecosystems continuously, which ultimately jeopardize human survival. As for the illegal logging activities in Law No. 41 of 1999 on Forestry contained in Article 50 paragraph (3) c, e, f, h, j and k letter. According to the Academic Manuscript Draft Law on the Prevention and Eradication of forest destruction, there are three (3) types of illegal logging which destroy the forests of Indonesia, namely: (1) Logging is done by legal operators who are technically administratively as an example by the owner or a forest concession of industrial timber estates or plantations but in practice, it has been in violation of the terms in the concession due to excess cut down in the forest industry or to take wood in a protected conservation area. These routes have been granted permission to selectively cut trees, (2) Illegal logging which is done by logging permit is obtained illegally issued by local government officials and is usually valid for one year. This practice was passed in 1999, but revoked by Government Regulation No. 34 of 2002, and (3) Theft of timber or often referred to as illegal logging. This type of logging is usually done by local people, coordinated by timber barons and middlemen to selectively cut trees that have high economic value in production forests, protected forests, as well as in protected areas. These people do not have the right to a legal permit from the government to cut down trees.

One of the forms of society's participation of logging in Sangir Balai Janggo is that providing information to the government about the destruction of forests. A form of public assistance for forest protection is by providing information to the government, if any there is one do illegal logging in forest area and if there is a violation of existing rules. Offenders who do will be penalized according to the degree of violation. From the observation of researchers with the local community, it was found that there are many among the people who do not obey the rules. There are still people who cut trees to open a new land then the land will be planted with palm oil or just to farming. It is commonly known that palm oil could cause an overgrown area became barren because the root of the palm can absorb water so that the soil becomes dry land.

The illegal logging is not a new problem occurred, but has happened many times after the sanction is no deterrent effect to the community. The reasons behind that are cutting down forests to open up new land or simply exploit forest resources such as wood to be sold to other regions. From the above cases, there should be participation and collaboration between government and society to equally protect the forest. However in participating communities also encountered problems, while the factors that constrain Society in Participating in the Protection of Forests in Sangir Balai Janggo namely: (1) The lack of intervention on the forest in Sangir Balai Janggo and (2) The lack of assistance provided by the government. The aid community expected is to provide assistance in the form of power by presenting the forestry police as a form to monitor forests in Sangir Balai Janggo because there is still additional number of them whose needed by the local community. Besides the government's efforts in improving the Community's Participation in the Protection of 
Forests in Sangir Balai Janggo. Based on interviews with the secretary subdistricts in Sangir Balai Janggo local government, the efforts made to improve community participation is to conduct socialization and counseling about the importance of forest preservation.

This effort is by assigning the forestry police to maintain security integrated forest and patrolling police together with the community to oversee the forest to remain intact forests from people who will carry out the destruction of forests, both of which cut the forest or other violations. Because the forestry police found it hard to find people who are destroying the forest/illegal logging if it is not supported by the local community. To overcome illegal logging, the people can make Indonesian Selective Logging System, known as TPTI a silvicultural system currently applied in Indonesia. With the progress towards sustainable forest management, harvesting techniques well known to Sustainable Logging are being implemented and promoted in various regions. RIL aims to reduce damage to residual trees, limit soil disturbance and impacts on wildlife by reducing the adverse consequences of the construction of roads and skid trails, as well as introduce directional felling felling and cutting climber cutting prior to felling (Gunarso 2009). RIL techniques have been integrated in a long term research strategy in order to develop strategies for sustainable forest management for research forest Sangir Balai Janggo. Research on the long-term impact and the direct impact of timber harvesting from an environmental and economic standpoint conducted to compare conventional logging techniques and RIL. The overall objective was to demonstrate the benefits of RIL in terms of economy and environment in order to promote RIL to be integrated into logging operations on a scale concessions.

\section{Conclusion}

The conclusions of this research is a form of community participation in the prevention of deforestation in Sangir Balai Janggo, Solok Selatan district is to provide information to the local government about the destruction of forests, not cut down trees illegally and impose penalties for offenders. Factors that constrain the public in participating in the prevention of deforestation in Sangir Balai Janggo, Selatan Solok, namely the lack of intervention on the forest in Sangir Balai Janggo and the lack of assistance provided by the local government. Furthermore, the efforts made by the government in Improving Public Participation in Poverty Deforestation in Sangir Balai Janggo is, with the socialization and counseling about the importance of forest preservation. Furthermore, also through cooperation between governments and communities to conduct patrols belonging integrated into society and the government. With the cooperation between the government and society will create sustainable development as equally we expect. With so expected there will be no people who perform destructions in the future forest. Which will lead to the emergence of other disasters such as landslides, flooding, erosion and global warming.

\section{References}

Embanaras, P. 2009. Partisipasi Masyarakat Dalam Program Kelompok Usaha Bersama (KUBE) di Kota Malang. Ilmu Administrasi Negara, FISH, UNESA.

Gunarso, P., Setyawati, T., Sunderland, T.C.H. and Shackleton, C. 2009. Pengelolaan Sumberdaya Hutan di Era Desentralisasi: Pelajaran yang Diperoleh dari Hutan Penelitian Malinau, Kalimantan Timur, Indonesia. CIFOR, Bogor, Indonesia.Hessel Nogi S Tangklisan. 2005. Manajemen Publik, PT. Grassindo, Jakarta.

Hermon, D. 2001. Studi Kontribusi Penggunaan Lahan dan Vegetasi Terhadap Karakteristik Epipedon. Tesis Magister. Program Pascasarjana Universitas Andalas Padang.

Hermon, D. 2009. Dinamika Permukiman dan Arahan Kebijakan Pengembangan Permukiman pada Kawasan Rawan Longsor di Kota Padang. Disertasi. IPB Bogor.

Hermon, D. 2010. Geografi Lingkungan: Perubahan Lingkungan Global. UNP Press.

Hermon, D. 2011. Studi Karakteristik Epipedon berdasarkan Penggunaan Lahan di Kecamatan X Koto Kabupaten Tanah Datar. Universitas Andalas. 
Hermon, D. 2012. Dinamika Cadangan Karbon Akibat Perubahan Tutupan Lahan Permukiman di Kota Padang Sumatera Barat. Forum Geografi: Indonesian Juornal of Spatial and Regional Analysis. Volume 26. Issue 1. p: 45-52. Uniiversitas Muhammadiyah Surakarta.

Hermon, D. 2012. Mitigasi Bencana Hidrometeorlogi: Banjir, Longsor, Degradasi Lahan, Ekologi, Kekeringan, dan Puting Beliung. UNP Press. Padang.

Hermon, D. 2014. Impacts of Land Cover Change on Climate Trend in Padang Indonesia. Indonesian Journal of Geography. Volume 46. Issue 2. p: 138-142. Fakultas Geografi Universitas Gajah Mada.

Hermon, D. 2015. Geografi Bencana Alam. Jakarta: PT RajaGrafindo Persada.

Hermon, D. 2016. Mitigasi Perubahan Iklim. Rajawali Pers (Radjagrafindo).

Hermon, D. 2016. Estimate of Changes in Carbon Stocks Based on Land Cover Changes in the Leuser Ecosystem Area (LEA) Indonesia. Forum Geografi. Volume 29. Issue 2. p: 188-196.

Hermon, D. 2016. The Change of Carbon Stocks and CO2 Emission as the Result of Land Cover Change for Tin Mining and Settlement in Belitung Island Indonesia.Journal of Geography and Earth Science. Volume 4. Issue 1. p: 17-30.

Hermon, D. 2017. Climate Change Mitigation. Rajawali Pers (Radjagrafindo).

Hermon, D., P. Iskarni., O. Oktorie and R. Wilis. 2017. The Model of Land Cover Change into Settlement Area and Tin Mining and its Affecting Factors in Belitung Island, Indonesia. Journal of Environment and Earth Science. Volume 7 No. 6. p: 32-39. IISTE.

Hermon, D., Ganefri., A. Putra and O. Oktorie. 2018. The Model of Mangrove Land Cover Change for the Estimation of Blue Carbon Stock Change in Belitung Island-Indonesia. International Journal of Applied Environmental Sciences. Volume 13. Issue 2. p: 191-202. Research India Publication.

Hermon, D., A. Putra and O. Oktorie. 2018. Suitability Evaluation of Space Utilization Based on Enviromental Sustainability at The Coastal Area of Bungus Bay in Padang City, Indonesia. International Journal of GEOMATE. Volume 14. Issue 41. p: 193-202. Geomate International Society.

Hermon, D. 2019. Evaluation of Physical Development of The Coastal Tourism Regions on Tsunami Potentially Zones in Pariaman City-Indonesia. International Journal of GEOMATE. Volume 17. Issue 59. p: 189-196. Geomate International Society.

Hermon, D., Ganefri, Erianjoni, I. Dewata, P. Iskarni and Alexander Syam. 2019. A Policy Model of Adaptation Mitigation and Social Risks The Volcano Eruption Disaster of Sinabung in Karo Regency-Indonesia. International Journal of GEOMATE. Volume 17. Issue 60. p: 190-196. Geomate International Society.

Kristian, A and O. Oktorie. 2018. Study of Coastal Mangrove Conservation in the World. Sumatra Journal of Disaster, Geography and Geography Education. Volume 2. Issue 1. p: 49-52

Meleong J.L. 2007.Metode Penelitian Kualitatif.Bandung:PT Remaja Rosdakarya.

Matinni, N. 2016. Model of Slum Settlement Policy in East Lombok, West Nusa Tenggara. Sumatra Journal of Disaster, Geography and Geography Education ISSN: 2580-4030 (Print) 2580-1775 (Online)Vol 2, No. 1, (pp. 84-89), June, 2018 http://sjdgge.ppj.unp.ac.id

Narindrani, F. 2018. Upaya Masyaraat dalam Pencegahan dan Pemberantasan Pembalakan Liar di Indonesia, Pusat Pengembangan Hukum, Badan Penelitian dan Pengembangan Hukum dan HAM R.I, Jakarta.

Oktorie, O. 2017. A Study of Landslide Areas Mitigation and Adaptation in Palupuah Subdistrict, Agam Regency, West Sumatra Province, Indonesia. Sumatra Journal of Disaster, Geography and Geography Education. Volume 1. Issue. 1. p: 43-49. Master Program of Geography Education

Oktorie, O. 2018. Model Kebijakan Responsif Pemulihan Bencana Letusan Gunung Sinabung. Jurnal Kapita Selekta Geografi. Volume 1. Issue 1. p: 15-20

Tanjung N. S., Dwi S and Cahyo T.W. 2017. Tingkat Partisipasi Masyarakat dalam Pengelolaan Hutan Nagari di Sumatera Barat, Program Studi Komunikasi Pembangunan Pertanian dan Pedesaan, Fakultas Ekologi Manusia Institut Pertanian Bogor, Bogor.

Slamet, Y. 1994. Pembangunan Masyarakat Berwawasan Partisipasi, Universitas Sebelas Maret, Surakarta. 